\title{
RNA as a conception
}

\author{
ANDREW D. ELLINGTON \\ Institute for Cellular and Molecular Biology, Center for Systems and Synthetic Biology, Department of Chemistry and Biochemistry, \\ University of Texas at Austin, Austin, Texas 78712, USA
}

RNA is of course a macromolecule that both carries information and mediates function. Indeed, this statement sort of defines the first two of what I consider to be three eras of RNA research. The Central Dogma more or less defines the first era, where the basic principles of molecular biology make RNA the messenger for how DNA talks to proteins. That said, even back then Crick and Orgel recognized that RNA could be much more, and as early as 1968 presciently foretold Tom Cech's and Sydney Altman's 1989 Nobel-worthy discovery that RNA could be a catalyst.

I believe that one of the major advances since then, due in large part to this journal, is the recognition that RNA is more than just a messenger and the odd, maybe-primitive-maybenot catalyst. RNA has taken on so many different roles now that it is hard to see it as other than a conception in search of multiple new functions. Just as the field of epigenetics has caused the research community to take a new look at DNA as a semi-Lamarckian molecule, microRNAs and siRNAs have caused scientists to recognize that RNA is a regulatory paradigm. But if we focus only on those two discoveries (the mirror images of one another, natural process and technology intervention) we discount the arcane world of riboswitches that extend RNA interactions from sequences to metabolites. We also miss out on the fact that regulation of translation is probably only one of many different regulatory functions that RNAs can carry out (e.g., regulation of epigenetic modification, regulation of editing).

Undoubtedly the broad brush that I am using here will strike many as overly general. Great, RNA can do lots of things, and that's a discovery? Well, yes, when you come from an earlier time when RNA was relegated to doing very few things, that is indeed a discovery. And it may be the appreciation of this change in mindset that is worth noting. When Crick and Orgel suggested that there might be many functions for RNA, their prognostications were in the realm of fantasy and were not realized for almost three decades. The discovery of ribozymes engendered in many ways a Renaissance for RNA, with new functions and features being discovered weekly (and often in the pages of RNA). But those discoveries were led by experimentation; once we were apprised that something might be "out there," scientists went after the unknown frontier with vigor. They were not led grudgingly to the conclusion, as Cech was (and brilliantly so), but were always ready to believe that RNA might be one of the pieces of a larger puzzle.

As a conception, though, it's not just what RNA has been discovered to do, but what it could do. If we were to design organisms from scratch, what would RNAs do? I sometimes point out that the discovery of allosterically regulated ribozymes actually preceded the discovery of riboswitches; our imaginations had already been made real by billions of years of evolution, we just didn't know it yet. Similarly, there have been a few researchers, often discounted, who speculated that extracellular RNAs might be very useful as information-carrying regulators. On cue we later find that RNAs in exosomes can perhaps serve as vehicles for cell-to-cell communication. The fields of nucleic acid nanotechnology and synthetic biology are rife with technologists discovering ever more fantastic uses for RNA. It might be wise to attend to these fields in the next twenty years of $R N A$ as heralds of what is possible in living systems, waiting to be discovered.
Corresponding author: ellingtonlab@gmail.com

Article and publication date are at http://www.rnajournal.org/cgi/doi/10. 1261/rna.050443.115. Freely available online through the RNA Open Access option.
(C) 2015 Ellington This article, published in RNA, is available under a Creative Commons License (Attribution-NonCommercial 4.0 International), as described at http://creativecommons.org/licenses/by-nc/4.0/. 

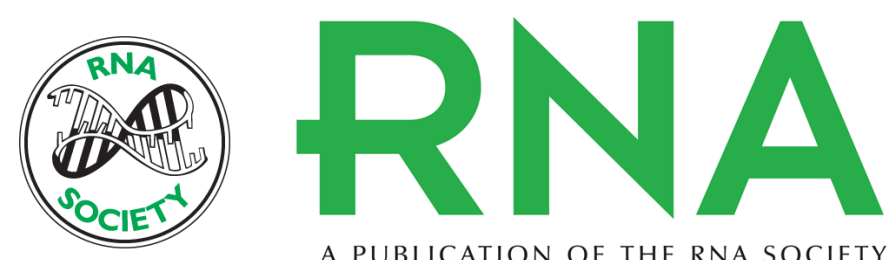

A PUBLICATION OF THE RNA SOCIETY

\section{RNA as a conception}

Andrew D. Ellington

RNA 2015 21: 608

Open Access Freely available online through the RNA Open Access option.

Creative This article, published in $R N A$, is available under a Creative Commons License

Commons (Attribution-NonCommercial 4.0 International), as described at

License http://creativecommons.org/licenses/by-nc/4.0/.

Email Alerting Receive free email alerts when new articles cite this article - sign up in the box at the Service top right corner of the article or click here.

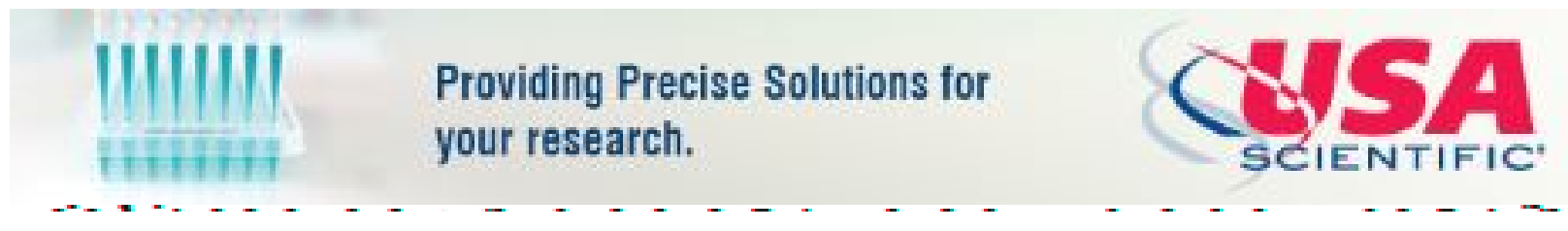

To subscribe to $R N A$ go to:

http://rnajournal.cshlp.org/subscriptions

(C) 2015 Ellington; Published by Cold Spring Harbor Laboratory Press for the RNA Society 